\title{
Bioinformatics Analysis of Some Functional Genes and Proteins Involved in Obesity-Induced Type 2 Diabetes
}

\author{
${ }^{1}$ Ehab M. Abdella, ${ }^{1}$ Rasha R. Ahmed, ${ }^{1}$ Mohamed B. Ashour, \\ ${ }^{1}$ Osama M. Ahmed, ${ }^{2}$ Sameh F. Abu Zid and ${ }^{1}$ Ayman M. Mahmoud \\ ${ }^{1}$ Experimental Obesity and Diabetes Research Lab, Department of Zoology, Faculty of Science, \\ ${ }^{2}$ Department Pharmacognosy, Faculty of Pharmacy, \\ Beni-Suef University, Beni-Suef, Egypt
}

\begin{abstract}
The incidence of type- 2 diabetes is rising rapidly worldwide, mainly because of the increase in the incidence of obesity, which is an important risk factor for this condition. Both obesity and type- 2 diabetes are complex genetic traits but they also share some nongenetic risk factors. Differences among individuals in their susceptibility to both these conditions probably reflect their genetic constitutions. The dramatic improvements in genomic and bioinformatic resources are accelerating the pace of gene discovery. It is tempting to speculate the key susceptible genes/proteins that bridges diabetes mellitus and obesity. In this regard, we evaluated the role of several genes/proteins that are believed to be involved in the evolution of obesity associated diabetes through thorough literature search. Also we analyzed the data pertaining to genes of these proteins extracted from the databases that are available online for free access. The functional cDNA sequences of these genes/proteins are extracted from National Center for Biotechnology Information (NCBI) and Ensembl Genome Browser. Our bioinformatic analysis reports 21 genes as ominous link with obesity associated diabetes. Also this study indicated that, adipose tissue is now known to express and secrete a variety of metabolites, hormones and cytokines that have been implicated in the development of insulin resistance. This bioinformatic study will be useful for future studies towards therapeutic inventions of obesity associated type-2 diabetes.
\end{abstract}

Keywords: Bioinformatics, Functional Genes, Obesity and Type Two Diabetes

\section{INTRODUCTION}

Type 2 diabetes and its complications may be prevented by either avoiding factors that trigger the disease process (primary prevention) or using therapies that modulate the disease process before the onset of clinical symptoms (secondary prevention). Accurate prediction and identification using biomarkers will be useful for disease prevention and initiation of proactive therapies to those individuals who are most likely to develop the disease. Recent technological advances in genetics, genomics, proteomics and bioinformatics offer great opportunities for biomarker discovery (Gedela et al., 2007).

Corresponding Author: Osama M. Ahmed, Division of Physiology, Department of Zoology, Faculty of Science, Beni-Suef University, Salah Salem Street, PO: 62514, Beni-Suef, Egypt Tel: 00201064006605
Obesity and its pathological complications, including atherosclerosis, hypertension and insulin resistance, have increased to reach epidemic dimensions nowadays (Bray, 2004). Some important factors for the development of these disorders are excessive accumulation of abdominal fat, which is known to play an important role in development of chronic inflammation; deposition of lipids into non-adipose tissues such as liver and muscles; atherosclerosis and chronic inflammation that increase risk in cardiovascular disorders and diabetes (Rajala and Scherer, 2003).

Adipose tissue is not just a site of energy storage but also behaves as a dynamic endocrine organ (Kershaw and Flier, 2004). It also plays an important role in energy expenditure, both as depot for energy-rich triglycerides and 
as a source for metabolic hormones as well (Bastard et al., 2006; Desruisseaux et al., 2007). Adipocytes produce a large number of so-called adipokines, such as leptin, adiponectin, Interleukin (IL)-1 $\beta$, IL-6 and Tumor Necrosis Factor-alpha (TNF- $\alpha$ ). Some of these molecules affect energy metabolism and insulin sensitivity in other tissues such as muscle and liver (Guilherme et al., 2008). During obesity, lipid storage in adipocytes is increased, which triggers the release of adipokines (Hotamisligil, 2006; Lupinacci et al., 2009). During inflammation, the mature adipocytes of the adipose tissue are responsible for increasing production of pro-inflammatory adipokines (Simons et al., 2005), including mentioned TNF- $\alpha$, IL$1 \beta$, IL-6. That disregulation contributes to obesity and chronic inflammation (Ouchi et al., 2003). The local increase of these adipokines have been directly related to insulin resistance, increasing lypolisis and increasing leptin levels (Desruisseaux et al., 2007).

The growing incidence of type 2 diabetes with increasing obesity reflects that obesity is an emerging risk factor for the progression of insulin resistance and subsequently to overt type-2 diabetes. Both in normoglycemic and hyperglycemic states, obese people exhibit a higher degree of hyperinsulinemia that correlates with the degree of insulin resistance, in order to maintain normal glucose tolerance (Bonadonna et al., 1990). Following attainment of certain point, the progressive deterioration of the metabolic milieu leads to eventual failure of hyperinsulinemia to compensate fully for the insulin resistance and thereby produces impaired glucose tolerance that progress to overt diabetes (DeFronzo et al., 1992). It has been presumed from genetic studies that there could be subset of genes whose expression changes with obesity and those genes whose expression further changes in the progression to type-2 diabetes (Elbers et al., 2007; Wang and Eckel, 2009; Ocana et al., 2010). However, the molecular basis that links obesity and diabetes is still largely unknown.

Bioinformatics has been in the focus since recent years for unraveling the structure and function of complex biological mechanisms. The analysis of primary gene products has further been considered as diagnostic and screening tool for disease recognition. Such strategies aim at investigating all gene products simultaneously in order to get a better overview about disease mechanisms and to find suitable therapeutic targets. Recently Gerken et al. (2007) performed bioinformatics analysis and reported that the variants in the fat mass and obesity associated gene are associated with increased body mass index in humans. Although Elbers et al. (2007) identified five overlapping chromosomal regions for obesity and diabetes. These results illustrate the importance of proteomics and bioinformatics approaches for identify new therapeutic invention of obesity is a challenging subject.
This study will therefore focus on potential implications of bioinformatics as a tool to identify novel metabolic patterns or markers associated with disease status. We will exemplify the potential of this method using the association between specific fats and development of obesity associated diabetes as a test case. In the present study we have employed online bioinformatics tools for the analysis of 21 genes, which are expected to play major role in obesity and diabetes, we sought to identify the common central gene/protein that connects both the metabolic disorders such as obesity and diabetes.

\section{MATERIALS AND METHODS}

\subsection{Methodology}

The present research aims at finding the genes/proteins responsible for obesity associated diabetes in two phases. The first phase of the research attempts to identify the candidate genes/proteins which are involved in these disorders through thorough literature search. The second phase of the research analyzes the data pertaining to genes of these proteins obtained from the databases that are available online for free access. The functional cDNA sequences of these genes/proteins are extracted from: (1) National Center for Biotechnology Information (NCBI), (http $\|_{w w w}$ ncbi.nih.nlm.gov), (2) Rat Genome Database (RGD) ( $<$ http://rgd.mcw.edu/rgdweb /search/search.html $>$ ), (3) Online Mendelian Inheritance in Man (OMIM), which can be accessed with the Entrez database searcher of the National Library of Medicine, Ensembl Genome Browser (http $\|$ www.ensembl.org/index.html), (4) Mouse Genome Informatics (MGI) website is hosted by The Jackson Laboratory, (5) HomoloGene, a tool of the National Center for Biotechnology Information (NCBI), is a system for automated detection of homologs (similarity attributable to descent from a common ancestor) among the annotated genes of several completely sequenced eukaryotic genomes and (6) GeneCards is a database of human genes that provides genomic, proteomic, transcriptomic, genetic and functional information on all known and predicted human genes. GeneCards is being developed and maintained by the Crown Human Genome Center at the Weizmann Institute of Science.

\section{RESULTS}

\subsection{First Phase (Literature Search)}

From literature search several adipocyte-secreted factors has been demonstrated to potentially link obesity, insulin resistance and type 2 diabetes mellitus. 
Ehab M. Abdella et al. / American Journal of Bioinformatics 1 (2): 87-98, 2012

Table 1. Showing thorough literature search of the genes/proteins that have been studied in the present study, which are believed to be involved in type-2 diabetics and obesity

\begin{tabular}{|c|c|}
\hline Gene name & Biological processes \\
\hline Adiponectin & $\begin{array}{l}\text { It enhances insulin resistance through activation of AMP protein kinase (AMPK). In addition, it also affects hepatic } \\
\text { glucose production by decreasing the mRNA expression of two essential gluconeogenic enzymes, phosphoenol pyruvate, } \\
\text { carboxykinase and glucose-6-phosphate (Kadowaki and Yamauchi, 2005; Antunna-Puente et al., 2008). }\end{array}$ \\
\hline $\begin{array}{l}\text { Resistin } \\
\text { (RETN) }\end{array}$ & $\begin{array}{l}\text { It links obesity to type- } 2 \text { diabetes. Several studies showed that resistin expression was increased in obese animals and } \\
\text { decreased in the presence of thiazolidinediones. A recent study revealed a decrease in fasting glucose, improved glucose } \\
\text { tolerance and enhanced insulin sensitivity in resistin gene knockout mice (Antunna-Puente et al., 2008). Moreover, resistin } \\
\text { inhibits adipocyte differentiation (Kim et al., 2001). In addition, the absence of resistin could allow activation of AMPK } \\
\text { and reduce gene expression encoding for hepatic gluconeogenic enzymes. On the other hand, resistin has a role in } \\
\text { inflammatory processes. It was associated with many inflammatory markers including C-reactive protein, TNF-a and IL-6. } \\
\text { Thus, resistin may represent a link between inflammation and metabolic signals (Rabe et al., 2008). }\end{array}$ \\
\hline $\begin{array}{l}\text { Leptin } \\
\text { (Obesity factor) }\end{array}$ & $\begin{array}{l}\text { It is an adipocyte-derived hormone and cytokine that regulates energy balance through a wide range of functions, } \\
\text { fatty acid metabolism and energy homeostasis. Several studies showed that, leptin play an important role in the central } \\
\text { regulation of body weight. It is now apparent that leptin also has important functions as a metabolic and neuroendocrine } \\
\text { hormone. Interestingly, plasma leptin levels correlate positively with body weight and it has been proposed that } \\
\text { hyperleptinemia may be important in the development of insulin resistance associated with type } 2 \text { and gestational diabetes } \\
\text { (Kahn and Flier, 2000). }\end{array}$ \\
\hline TNF-a & $\begin{array}{l}\text { It is a proinflammatory cytokine with a wide range of biologic effects including the stimulation of the production of } \\
\text { prostaglandins, platelet-activating factor and plasminogen activator inhibitor; chemotaxis; the induction of adhesion } \\
\text { molecules expression; the synthesis of other inflammatory mediators, inhibits lipolysis and impairs insulin-induced } \\
\text { glucose uptake, thus leading to insulin resistance and weight loss (Antunna-Puente et al., 2008). }\end{array}$ \\
\hline IL-6 & $\begin{array}{l}\text { Cytokines appear to be major regulators of adipose tissue metabolism. Expression studies show that adipocytes can } \\
\text { synthesize Tumor Necrosis Factor Alpha (TNF- } \alpha \text { ) and several Interleukin (IL) notably IL-1 } \beta \text { and IL-6. IL-1 } \beta \text { is well } \\
\text { known to suppress adipocyte differentiation and lipoprotein lipase expression and activity by inhibiting the expression } \\
\text { of fatty acid transport protein in adipose tissue. In addition, It is an important regulator of adipogenesis, food intake and } \\
\text { energy expenditure (Carey et al., 2008; Wang et al., 2010). }\end{array}$ \\
\hline RBP-4 & $\begin{array}{l}\text { Recent studies indicated that RBP- } 4 \text { serum level was elevated in insulin-resistant rodents and in obese or type } 2 \text { diabetic } \\
\text { humans. In fact, there is a positive correlation between RBP-4 plasma levels and insulin resistance severity in obese, } \\
\text { glucose intolerant, type } 2 \text { diabetics and in non-obese subjects with strong family background (Yang et al., 2005; } \\
\text { Antunna-Puente et al., 2008). }\end{array}$ \\
\hline Adipsin & $\begin{array}{l}\text { It is a serine protease and part of alternative complement pathway (complement factor D). it is discovered as a factor } \\
\text { expressed in a differentiation-dependent manner in adipocyte cell lines and its expression was greatly reduced in animal } \\
\text { models of obesity. Thus this polypeptide may act as a lipostatic signal and may have a role linking insulin resistance with } \\
\text { obesity (Trayhum and Beattie, 2001; Fruhbeck et al., 2004). }\end{array}$ \\
\hline LPL & $\begin{array}{l}\text { It plays a major role in the metabolism and transport of lipids. It is the enzyme responsible for the hydrolysis of core } \\
\text { Triglycerides (TGs) in chylomicrons and very Low-Density Lipoproteins (VLDLs), producing chylomicron remnants and } \\
\text { Intermediate-Density Lipoproteins (IDLs), respectively (Wang and Eckel, 2009). Besides its hydrolytic activity, LPL can } \\
\text { interact with lipoproteins to anchor them to the vessel wall and facilitate lipoprotein particle uptake (Rinninger et al., 1998; } \\
\text { Strauss et al., 2001; Long et al., 2006). }\end{array}$ \\
\hline Ghrelin & $\begin{array}{l}\text { It is a novel 28-amino-acid peptide esterified with octanoic acid on Ser } 3 \text { that is principally released from Gr cells in the } \\
\text { oxyntic mucosa of the stomach (Chung et al., 2007). Ghrelin has been identified as an endogenous ligand for the GH } \\
\text { Secretagogue Receptor (GHS-R) (Kojima et al., 1999). Ghrelin stimulates GH release via the hypothalamus and direct } \\
\text { pituitary pathways and induces a positive energy balance by stimulating food intake while decreasing fat use through GH- } \\
\text { independent mechanisms (Nakazato et al., 2001). Ghrelin also has numerous peripheral actions including direct effects on } \\
\text { exocrine and endocrine pancreatic functions, carbohydrate metabolism, the cardiovascular system, gastric secretion, } \\
\text { stomach motility and sleep (Kojima and Kangawa, 2005; Ghigo et al., 2005) }\end{array}$ \\
\hline Chemerin & $\begin{array}{l}\text { It is crucial for normal adipocyte differentiation and modulate the expression of adipocyte gene involved in glucose and } \\
\text { lipid homeostasis by affecting glucose transporter-4, fatty acid synthase and adiponectin via its own receptors. In addition, } \\
\text { it enhances insulin stimulated glucose uptake and Insulin Receptor Substrat-1 (IRS-1) tyrosin phosphorylation in 3T3-L1 } \\
\text { adipocytes, suggesting that chemerin may increase insulin sensitivity in adipose tissue (Roh et al., 2007; Cash et al., 2008; } \\
\text { Takahashi et al., 2008). }\end{array}$ \\
\hline Visfatin & $\begin{array}{l}\text { It was recently discovered as a new adipokines. Similarly to insulin, visfatin in vitro enhanced glucose uptake by } \\
\text { monocytes and adipocytes and inhibited hepatocytes glucose release (Gualillo et al., 2007). In addition, visfatin amplifies } \\
\text { adipocyte differentiation. Also, it has insulin mimetic effects can bind to and activate insulin receptors. This hormone also } \\
\text { affects insulin-transduction pathway as it induces tyrosine phosphorylation of insulin receptor substrate-1 and -2 and } \\
\text { activate phosphorylinositol-3-kinase B and MAP kinase (Antunna-Puente et al., 2008). }\end{array}$ \\
\hline Omentin & $\begin{array}{l}\text { Plasma omentin-1 levels were inversely correlated with obesity and insulin resistance and positively correlated with } \\
\text { adiponectin and HDL-levels (De Souza et al., 2007; Rabe et al., 2008). Interestingly, omentin increases insulin-stimulated } \\
\text { glucose uptake in both omental and subcutaneous adipocytes and promotes AKt phosphorylation (Yang et al., 2006; } \\
\text { Antunna-Puente et al., 2008). }\end{array}$ \\
\hline
\end{tabular}


Ehab M. Abdella et al. / American Journal of Bioinformatics 1 (2): 87-98, 2012

Table 1. Continue

PAI-1 PAI-1 inhibits the serine proteases tPA and uPA/urokinase and hence is an inhibitor of fibrinolysis, the physiological process that degrades blood clots. Also, PAI-1 inhibits the activity of matrix metalloproteinases, which play a crucial role in invasion of malignant cells across the basal lamina (Binder et al., 2002). In addition, it is implicated in adipose tissue development and in the control of insulin signaling in adipocytes. Also, it impairs insulin action. Thus, PAI-1 inhibitors may serve to improve insulin action (Hertig and Rondeau, 2004).

FABP2 The intracellular Fatty Acid-Binding Proteins (FABPs) belong to a multigene family with nearly twenty identified members. FABPs are divided into at least three distinct types, namely the hepatic-, intestinal- and cardiac-type. They form 14-15 kDa proteins and are thought to participate in the uptake, intracellular metabolism and/or transport of long-chain fatty acids. They may also be responsible in the modulation of cell growth and proliferation. Intestinal fatty acid-binding protein 2 gene contains four exons and is an abundant cytosolic protein in small intestine epithelial cells. This gene has a polymorphism at codon 54 that identified an alanine-encoding allele and a threonine-encoding allele. Thr- 54 protein is associated with increased fat oxidation and insulin resistance (Glatz et al., 1997; Storch and Thumser, 2000).

PPAR- $\gamma \quad$ The members of the PPAR-family, PPAR $\alpha$, PPAR $\beta / \delta$ and PPAR $\gamma$ play an important role in the regulation of lipid and glucose metabolism (Fliegner et al., 2008). Disturbance of PPAR pathways promotes the progression of diseases, such as obesity, type 2 diabetes, cardiovascular diseases, cancer, neurodegenerative diseases, hypertension and chronic inflammation (Michalik et al., 2006; Hamblin et al., 2009; Khateeb et al., 2010). Once activated by a ligand, PPARs recruit transcriptional co-activators, which are necessary to initiate target gene transcription. The target genes are mainly involved in the energy homeostasis and include genes from the B-oxidation, the free fatty acid translocase (CD36), the Medium Chain Acetyl Dehydrogenase (MCAD), the Acetyl-CoA-Oxidase (ACO) and the carbohydrate oxidative pathways like the insulin-insensitive (GLUT1) and the insulin-sensitive (GLUT4) glucose transporters. These genes were first established as target genes of PPAR $\alpha$ and $\beta / \delta$, but recently it was shown that CD36, ACO and GLUT1 are also PPAR $\gamma$ target genes (Li et al., 2008). PPAR $\gamma$ is mainly involved in fat cell differentiation and lipid storage, but is also involved in the regulation of glucose homeostasis and cardiac energy metabolism (Hamblin et al., 2009). So that, PPAR- $\gamma$ ligand could potentiate the insulin effect and improve insulin signaling via increasing tyrosine phosphorylation of the insulin receptors, as well as the serine phosphorylation of Akt/PKB (Wallberg et al., 2003). In addition, PPARs have been implicated as regulators of inflammatory processes and tissue repair. Thus, mechanisms of PPAR-induced pathways are under intensive investigation

Aguti It has been demonstrated to be an inverse agonist of melanocortin receptors, specifically, MC3-R and MC4-R. The

(AgRP) melanocortin receptors, MC3-R and MC4-R, are directly linked to metabolism and body weight control. These receptors are activated by the peptide hormone $\alpha$-MSH (melanocyte-stimulating hormone) and antagonized by the agouti-related protein (Backberg et al., 2004). The appetite stimulating effects of AgRP are inhibited by the hormone leptin and activated by the hormone ghrelin. Adipocytes secrete leptin in response to food intake. This hormone acts in the arcuate nucleus and inhibits the AgRP/NPY neuron from releasing orexigenic peptides (Enriori et al., 2007). Ghrelin has receptors on NPY/AgRP neurons that stimulate the secretion of NPY and AgRP to increase appetite. AgRP is stored in intracellular secretory granules and is secreted via a regulated pathway (Creemers et al., 2006). The transcriptional and secretory action of AgRP is regulated by inflammatory signals (Scarlett et al., 2008). Levels of AgRP are increased during periods of fasting. It has been found that AgRP stimulates the hypothalamic-pituitary-adrenocortical axis to release ACTH, cortisol and prolactin. It also enhances the ACTH response to IL-1-beta, suggesting it may play a role in the modulation of neuroendocrine response to inflammation (Xiao et al., 2003).

nSREBP-1 Shimomura et al. (1998) reported that, nuclear SREBP-1 was shown to promote adipocyte differentiation in cultured 3T3L1 preadipocytes. In addition, this protein have the ability to bind and activate the promoters of genes involved in cholesterol biosynthesis and uptake. The documented direct targets of nSREBP include 3-hydroxy-3-methyl glutaryl coenzyme A (HMG-CoA) synthase, HMG-CoA reductase (enzymes involved in cholesterol biosynthetic pathway), fatty acid synthase and glycerol 3-phosphate acyl-transferase. This nuclear protein also activate transcription of the low density lipoprotein receptors which mediates uptake of cholesterol and fatty acids (Brown and Goldstein, 1997).

FOXO1 It is a family of winged helix/forkhead box factors which are crucial for adipocyte differentiation and have prominent roles in insulin signaling pathways (Armoni et al., 2006). In addition, convergence of nuclear receptors and forkhead pathways in general and of FOXO1 and PPAR- $\gamma$ in particular has been implicated in the pathophysiological states of insulin resistance and diabetes. Several studies showed that, FOXO1 also functions in adipose tissue to couple insulin signaling to adipogenesis, which involves switching pre-adipocytes from proliferation to terminal differentiation. Also, FOXO1 directly or indirectly represses expression of PPAR- $\gamma$ gene which represses GLUT4 promoter activity. Based on this evidence, the repression of PPAR- $\gamma$ by FOXO1 leads to GLUT4 up-regulation and results in enhanced glucose transport and cellular insulin sensitivity (Nakae et al., 2002; 2003; Tran et al., 2003).

$11 \beta-H S D-1 \quad$ Data from rodents provide evidence for a casual role of 11ß-HSD-1 in the development of obesity and its complications (Masuzaki et al., 2001; Boullu-Ciocca et al., 2005). Recent studies indicated that, 11ß-HSD-1 expression was increased in visceral adipose tissue in obese patients. However, 11ß-HSD-1 inhibition had therapeutic effect in murine models of metabolic syndrome or type 2 diabetes (Hermanowski-Vosatka et al., 2005; Desbriere et al., 2006).

Apelin Apelin is active peptide regulate insulin resistance by influencing the circulating adiponectin level and the expression of brown adipose tissue uncoupling proteins and energy expenditure in mice (Gualillo et al., 2007; Higuchi et al., 2007). Vaspin, a visceral adipose tissue-derived serine protease inhibitor, is strongly expressed in visceral adipose tissue in rat, mouse and human obesity (Hida et al., 2005). However, human mRNA was also expressed in subcutaneous adipose tissue (Rabe et al., 2008). Administration of recombinant human vaspin to a mouse model of diet-induced obesity improved glucose tolerance and insulin sensitivity, suggesting that vaspin may represent an insulin sensitizing adipokines (Antunna-Puente et al., 2008; Rabe et al., 2008). 
Ehab M. Abdella et al. / American Journal of Bioinformatics 1 (2): 87-98, 2012

Table 2. Showing comparative gene map data of the genes/proteins that have been studied in the present study, which are believed to be involved in type-2 diabetics and

\begin{tabular}{|c|c|c|c|c|c|c|c|c|c|c|c|c|}
\hline \multirow[b]{2}{*}{ Gene } & \multicolumn{4}{|c|}{ Rattus norvegicus } & \multicolumn{4}{|l|}{ Mus musculus } & \multicolumn{4}{|l|}{ Homo sapiens } \\
\hline & Map name & $\begin{array}{l}\text { Map } \\
\text { position }\end{array}$ & $\begin{array}{l}\text { Chr. } \\
\text { number }\end{array}$ & $\begin{array}{l}\text { Chr. } \\
\text { position }\end{array}$ & Map name & $\begin{array}{l}\text { Map } \\
\text { position }\end{array}$ & $\begin{array}{l}\text { Chr. } \\
\text { number }\end{array}$ & $\begin{array}{l}\text { Chr. } \\
\text { position }\end{array}$ & Map name & Map position & $\begin{array}{l}\text { Chr. } \\
\text { number }\end{array}$ & $\begin{array}{l}\text { Chr. } \\
\text { position }\end{array}$ \\
\hline Adiponectin & $\begin{array}{l}\text { genome } \\
\text { assembly } 3.1\end{array}$ & 79965888 & 11 & $\mathrm{q} 23$ & $\begin{array}{l}\text { Mouse genome } \\
\text { assembly } 36.1\end{array}$ & 23146609 & 16 & 16 B3-B4 & $\begin{array}{l}\text { human genome } \\
\text { assembly }\end{array}$ & 188043164 & 3 & $\mathrm{q} 27$ \\
\hline Resistin & $\begin{array}{l}\text { Rat Celera } \\
\text { Assembly }\end{array}$ & 3566836 & 12 & $\mathrm{p} 12$ & $\begin{array}{l}\text { Mouse Celera } \\
\text { Assembly }\end{array}$ & 3886118 & 8 & $8 \mathrm{~A} 1$ & $\begin{array}{l}\text { Human Celera } \\
\text { Assembly }\end{array}$ & 7605160 & 19 & $\mathrm{p} 13.2$ \\
\hline Leptin & $\begin{array}{l}\text { Rat Celera } \\
\text { Assembly }\end{array}$ & 52779315 & 4 & $\mathrm{q} 22$ & $\begin{array}{l}\text { Mouse Celera } \\
\text { Assembly }\end{array}$ & 29063769 & 6 & $6 \mathrm{~A} 3.3$ & $\begin{array}{l}\text { Human Celera } \\
\text { Assembly }\end{array}$ & 122684619 & 7 & $\mathrm{q} 31.3$ \\
\hline TNF- $\alpha$ & $\begin{array}{l}\text { genome } \\
\text { assembly } 3.1\end{array}$ & 64647455 & 10 & q25 & $\begin{array}{l}\text { Mouse Genome } \\
\text { Assembly } 36.1\end{array}$ & 78336352 & 11 & $11 \mathrm{~B} 5$ & $\begin{array}{l}\text { human genome } \\
\text { assembly }\end{array}$ & 23686912 & 17 & $\mathrm{q} 22-\mathrm{q} 23$ \\
\hline IL-6 & $\begin{array}{l}\text { genome } \\
\text { assembly } 3.1\end{array}$ & 456798 & 4 & $\mathrm{q} 11$ & $\begin{array}{l}\text { Mouse genome } \\
\text { assembly } 36.1\end{array}$ & 30339701 & 5 & $5 \mathrm{~B} 1$ & $\begin{array}{l}\text { Human Celera } \\
\text { Assembly }\end{array}$ & 22752396 & 7 & \\
\hline RBP-4 & $\begin{array}{l}\text { Rat Celera } \\
\text { Assembly }\end{array}$ & $2.33 \mathrm{E}+08$ & 1 & $\mathrm{q} 53$ & $\begin{array}{l}\text { Mouse Celera } \\
\text { Assembly }\end{array}$ & 38908311 & 19 & 19 D1 & $\begin{array}{l}\text { human genome } \\
\text { assembly }\end{array}$ & 95341583 & 10 & q23-q24 \\
\hline Adipsin & $\begin{array}{l}\text { genome } \\
\text { assembly } 3.1\end{array}$ & 11325546 & 7 & q11 & $\begin{array}{l}\text { Mouse Celera } \\
\text { Assembly }\end{array}$ & 80905663 & 10 & $10 \mathrm{C} 1$ & $\begin{array}{l}\text { Human Celera } \\
\text { Assembly }\end{array}$ & 784591 & 19 & $\mathrm{p} 13.3$ \\
\hline LPL & $\begin{array}{l}\text { genome } \\
\text { assembly } 3.1\end{array}$ & 22532512 & 16 & p14 & $\begin{array}{l}\text { Mouse Celera } \\
\text { Assembly }\end{array}$ & 71423790 & 8 & $8 \mathrm{~B} 3.3$ & $\begin{array}{l}\text { human genome } \\
\text { assembly }\end{array}$ & 19841057 & 8 & $\mathrm{p} 22$ \\
\hline Ghrelin & $\begin{array}{l}\text { genome } \\
\text { assembly } 3.1\end{array}$ & $1.5 \mathrm{E}+08$ & 4 & $\mathrm{q} 42$ & $\begin{array}{l}\text { Mouse genome } \\
\text { assembly } 36.1\end{array}$ & 113666113 & 6 & $6 \mathrm{E} 3$ & $\begin{array}{l}\text { human genome } \\
\text { assembly }\end{array}$ & 10302433 & 3 & p26-p25 \\
\hline Chemerin & $\begin{array}{l}\text { Rat Celera } \\
\text { Assembly }\end{array}$ & 72460060 & 4 & $\mathrm{q} 24$ & $\begin{array}{l}\text { Mouse Celera } \\
\text { Assembly }\end{array}$ & 49080699 & 6 & $6 \mathrm{~B} 2.3$ & $\begin{array}{l}\text { Human Celera } \\
\text { Assembly }\end{array}$ & 144592497 & 7 & \\
\hline Visfatin & $\begin{array}{l}\text { genome } \\
\text { assembly } 3.1\end{array}$ & 51132285 & 6 & q16 & $\begin{array}{l}\text { Mouse genome } \\
\text { assembly } 36.1\end{array}$ & 33505340 & 12 & $12 \mathrm{~B} 1$ & $\begin{array}{l}\text { human genome } \\
\text { assembly }\end{array}$ & 105495899 & 7 & $\mathrm{q} 22.3$ \\
\hline Omentin & $\begin{array}{l}\text { Genome } \\
\text { Assembly } 3.4\end{array}$ & 87445119 & 13 & $\mathrm{q} 24$ & $\begin{array}{l}\text { Mouse genome } \\
\text { assembly } 36.1\end{array}$ & 173448254 & 1 & $1 \mathrm{H} 2$ & $\begin{array}{l}\text { human genome } \\
\text { assembly }\end{array}$ & 157659404 & 1 & $\mathrm{q} 21.3$ \\
\hline PAI-1 & $\begin{array}{l}\text { Rat Celera } \\
\text { Assembly }\end{array}$ & 21377028 & 12 & q11-q12 & $\begin{array}{l}\text { Mouse Celera } \\
\text { Assembly }\end{array}$ & 134078340 & 5 & $5 \mathrm{G} 2$ & $\begin{array}{l}\text { Human Celera } \\
\text { Assembly }\end{array}$ & 95778744 & 7 & $\mathrm{q} 21.3-\mathrm{q} 22$ \\
\hline FABP2 & $\begin{array}{l}\text { genome } \\
\text { assembly } 3.1\end{array}$ & 219554563 & 2 & $\mathrm{q} 42$ & $\begin{array}{l}\text { Mouse Genome } \\
\text { Assembly } 36.1\end{array}$ & 122598310 & 3 & $3 \mathrm{G} 1$ & $\begin{array}{l}\text { human genome } \\
\text { assembly }\end{array}$ & 120596008 & 4 & q28-q31 \\
\hline $\operatorname{PPAR} \gamma$ & $\begin{array}{l}\text { Rat Celera } \\
\text { Assembly }\end{array}$ & 137316681 & 4 & $\mathrm{q} 42$ & $\begin{array}{l}\text { Mouse Celera } \\
\text { Assembly }\end{array}$ & 117199637 & 6 & $6 \mathrm{~F} 3-\mathrm{F} 1$ & $\begin{array}{l}\text { Human Celera } \\
\text { Assembly }\end{array}$ & 12266744 & 3 & $\mathrm{p} 25$ \\
\hline $\begin{array}{l}\text { Aguti } \\
\text { (AgRP) }\end{array}$ & $\begin{array}{l}\text { genome } \\
\text { assembly } 3.1\end{array}$ & 35391672 & 19 & q11 & $\begin{array}{l}\text { Mouse Genome } \\
\text { Assembly } 36.1\end{array}$ & 108090598 & 8 & 8 D1-D2 & $\begin{array}{l}\text { human genome } \\
\text { assembly }\end{array}$ & 66073974 & 16 & $\mathrm{q} 22$ \\
\hline nSREBF-1 & $\begin{array}{l}\text { Rat Celera } \\
\text { Assembly }\end{array}$ & 44264875 & 10 & $\mathrm{q} 22$ & $\begin{array}{l}\text { Mouse Genome } \\
\text { Assembly } 36.1\end{array}$ & 60012591 & 11 & $11 \mathrm{~B} 2$ & $\begin{array}{l}\text { human genome } \\
\text { assembly }\end{array}$ & 17656110 & 17 & $\mathrm{p} 11.2$ \\
\hline FOXO1 & $\begin{array}{l}\text { Rat Celera } \\
\text { Assembly }\end{array}$ & 130806706 & 2 & q26 & $\begin{array}{l}\text { Mouse Celera } \\
\text { Assembly }\end{array}$ & 52001471 & 3 & $3 \mathrm{C}$ & $\begin{array}{l}\text { Human Celera } \\
\text { Assembly }\end{array}$ & 22187272 & 13 & q14.1 \\
\hline $11 \beta-H S D 1$ & $\begin{array}{l}\text { genome } \\
\text { assembly } 3.1\end{array}$ & 109252609 & 13 & $\mathrm{q} 27$ & $\begin{array}{l}\text { Mouse Genome } \\
\text { Assembly } 36.1\end{array}$ & 195047834 & 1 & $1 \mathrm{H} 6$ & $\begin{array}{l}\text { human genome } \\
\text { assembly }\end{array}$ & 206266585 & 1 & $\mathrm{q} 32-\mathrm{q} 41$ \\
\hline Apelin & $\begin{array}{l}\text { genome } \\
\text { assembly } 3.1\end{array}$ & 134460719 & $\mathrm{X}$ & $\mathrm{q} 35$ & $\begin{array}{l}\text { Mouse Genome } \\
\text { Assembly } 36.1\end{array}$ & 45378323 & $\mathrm{X}$ & $\mathrm{X} \mathrm{A} 3.2$ & $\begin{array}{l}\text { Human Celera } \\
\text { Assembly }\end{array}$ & 129165798 & $\mathrm{X}$ & $\mathrm{q} 25$ \\
\hline $\begin{array}{l}\text { Vaspin } \\
\text { (Serpina12) }\end{array}$ & $\begin{array}{l}\text { Rat Celera } \\
\text { Assembly }\end{array}$ & 120432630 & 6 & $\mathrm{q} 32$ & $\begin{array}{l}\text { Mouse Genome } \\
\text { Assembly } 36.1\end{array}$ & 105266979 & 12 & $12 \mathrm{~F} 1$ & $\begin{array}{l}\text { human genome } \\
\text { assembly }\end{array}$ & 94023372 & 14 & $\mathrm{q} 32.13$ \\
\hline
\end{tabular}

These adipocytokines comprise mediators (Table 1) such as adiponectin, resistin, leptin (obesity factor), Tumor Necrosis Factor-Alpha (TNF- $\alpha$ ), Interleukin-6 (IL-6), Retinol Binding Protein-4 (RBP-4), adipsin, Lipoprotein Lipase (LPL), ghrelin, chemerin, visfatin, omentin, Plasminogen Activator Inhibitor-1 (PAI-1), Fatty Acid Binding Protein-2 (FABP2), Peroxisome Proliferators-Activated Receptor- $\gamma$ (PPAR $\gamma$ ), Aguti (AgRP), nuclear Sterol Regulatory Element-Binding Proteins-1c (nSREBP-1), winged-helix-forkhead box class O-1 (FOXO-1), 11 3 -Hydroxysteroid Dehydrogenase type-1 (11 $\beta$-HSD-1), apelin and vaspin. These adipose derived factors are presently subjected to intensive research concerning their involvement in the regulation of adipose tissue physiology and in particular, their potential implication in insulin resistance, obesity and diabetes. In addition, most of these mediators may directly or indirectly interact with insulin receptors and/or insulin signaling, leading to insulin resistance in liver and peripheral tissues, especially in visceral obesity. The roles and mechanisms of some of the most important adipokines were suggested by some publications illustrated in Table 1. 
Ehab M. Abdella et al. / American Journal of Bioinformatics 1 (2): 87-98, 2012

Table 3. Showing gene ontology data of the genes/proteins that have been studied in the present study, which are believed to be involved in type-2 diabetics and obesity

\begin{tabular}{|c|c|c|c|c|c|c|c|}
\hline \multirow[b]{2}{*}{ Gene } & \multirow[b]{2}{*}{ Secreted tissues } & \multicolumn{4}{|l|}{ Identifiers } & \multicolumn{2}{|l|}{ gene ontology } \\
\hline & & MGD & OMIM & Homolo-gene & Array IDs & Molecular function & Biological activities \\
\hline Adiponectin & Adipose tissues & 106675 & 605441 & 3525 & rc_AI176736_at & hormone activity & $\begin{array}{l}\text { - Positive regulation of I-kappaB kinase/NF-kappaB cascade } \\
\text { - Negative regulation of gluconeogenesis } \\
\text { - Positive regulation of fatty acid metabolic process } \\
\text { - Positive regulation of glucose import }\end{array}$ \\
\hline Resistin & $\begin{array}{l}\text { Brain, cerebral } \\
\text { cortex, lung }\end{array}$ & 1888506 & 605565 & 10703 & rc_AA819348_at & hormone activity & $\begin{array}{l}\text { - Increase transcriptional events leading to an increased } \\
\text { expression of several pro-inflammatory cytokines } \\
\text { - Serve as a link between obesity and T2DM }\end{array}$ \\
\hline Leptin & Adipocytes & 104663 & 164160 & 193 & D49653_s_at & growth factor activity & $\begin{array}{l}\text { - Regulation of gluconeogenesis } \\
\text { - Regulation of insulin secretion } \\
\text { - Regulation of intestinal cholesterol absorption }\end{array}$ \\
\hline TNF-a & $\begin{array}{l}\text { Numerous cells, } \\
\text { but mainly } \\
\text { macrophages and } \\
\text { lymphocytes }\end{array}$ & 104798 & 191160 & 496 & rc_AA943494_at & Cytokine activity & $\begin{array}{l}\text { - Negative regulation of appetite } \\
\text { - Induction of apoptosis via death domain receptors } \\
\text { - Regulation of cell proliferation } \\
\text { - Positive regulation of I-kappaB kinase/NF-kappaB cascade } \\
\text { - Negative regulation of glucose import }\end{array}$ \\
\hline IL-6 & $\begin{array}{l}\text { fibroblasts, } \\
\text { lymphocytes, } \\
\text { adipose tissues }\end{array}$ & 96559 & 147620 & 502 & M26745cds_s_at & Cytokine activity & $\begin{array}{l}\text { - Cell-cell signaling } \\
\text { - Positive regulation of cell proliferation } \\
\text { - Negative regulation of apoptosis }\end{array}$ \\
\hline RBP-4 & Adipocyte tissue & 97879 & 180250 & 4908 & K03045cds_r_at & Transporter activity & Transport, visual perception and response to stimulus \\
\hline Adipsin & $\begin{array}{l}\text { White fat } \\
\text { adipocytes }\end{array}$ & & 134350 & & GE1112269 & $\begin{array}{l}\text { Stimulates glucose } \\
\text { transport in fat cells } \\
\text { and inhibits lipolysis }\end{array}$ & $\begin{array}{l}\text { - The encoded protein is a component of the alternative } \\
\text { complement pathway best known for its role in humoral } \\
\text { suppression of infectious agents and the encoded protein has } \\
\text { a high level of expression in fat, suggesting a role for adipose } \\
\text { tissue in immune system biology. }\end{array}$ \\
\hline LPL & Adipose tissues & 96820 & 238600 & 200 & L03294_g_at & lipid transporter activity & $\begin{array}{l}\text { - Regulate fatty acid metabolic process } \\
\text { - Regulate lipid catabolic process }\end{array}$ \\
\hline Ghrelin & $\begin{array}{l}\text { produced by } \mathrm{P} / \mathrm{D} 1 \\
\text { cells lining the } \\
\text { fundus of stomach }\end{array}$ & 1930008 & 605353 & 9487 & A_44_P420046 & Hormone activity & $\begin{array}{l}\text { - positive regulation of appetite } \\
\text { - positive regulation of body size }\end{array}$ \\
\hline Gene & Secreted tissues & MGD & OMIM & Homolo-gene & Array IDs & Molecular function & Biological Activities \\
\hline Chemerin & $\begin{array}{l}\text { Hepatocytes, white } \\
\text { adipose tissue }\end{array}$ & 1918910 & 601973 & 2167 & rc_AI176061_at & $\begin{array}{l}\text { cell differentiation } \\
\text { activities }\end{array}$ & - Retinoid metabolic process \\
\hline Visfatin & $\begin{array}{l}\text { Visceral fat } \\
\text { Adipocytes }\end{array}$ & 1929865 & 608764 & 4201 & rc_AI177755_at & cytokine activity & $\begin{array}{l}\text { - cell-cell signaling, } \\
\text { - positive regulation of cell proliferation }\end{array}$ \\
\hline $\begin{array}{l}\text { Omentin } \\
\text { PAI-1 }\end{array}$ & $\begin{array}{l}\text { visceral adipose tissue } \\
\text { Endothelium cells } \\
\text { lining blood vessels, } \\
\text { adipose tissue }\end{array}$ & $\begin{array}{l}3057189 \\
97608\end{array}$ & $\begin{array}{l}609873 \\
173360\end{array}$ & $\begin{array}{l}79454 \\
68070\end{array}$ & GE1137951 & $\begin{array}{l}\text { Sugar binding activity } \\
\text { endopeptidase inhibitor } \\
\text { activity and plasminogen } \\
\text { activator activity }\end{array}$ & $\begin{array}{l}\text { - Signal transduction } \\
\text { - glucose homeostasis } \\
\text { - many other biological processes; } \\
\text { associated with diabetes Mellitus }\end{array}$ \\
\hline FABP2 & Adipocyte tissue & 95478 & 134640 & 107 & A_43_P11691 & $\begin{array}{l}\text { lipid transporter activity } \\
\text { and fatty acid binding }\end{array}$ & $\begin{array}{l}\text { Increase partitioning of glucose to } \\
\text { triacylglycerols and enhance insulin resistance }\end{array}$ \\
\hline PPAR-g & $\begin{array}{l}\text { vascular smooth } \\
\text { muscle cells, } \\
\text { cells, endothelial } \\
\text { adipocytes }\end{array}$ & 97747 & 601487 & 7899 & A_42_P462474 & transcription factor activity & $\begin{array}{l}\text { - Regulate lipid metabolic process } \\
\text { - epithelial cell differentiation } \\
\text { - regulation of fat cell differentiation } \\
\text { - positive regulation of transcription }\end{array}$ \\
\hline $\begin{array}{l}\text { Aguti } \\
\text { (AgRP) }\end{array}$ & Macrophages & 892013 & 602311 & 7184 & A_44_P257522 & $\begin{array}{l}\text { Receptor binding, } \\
\text { neuro-peptide and } \\
\text { hormone activity }\end{array}$ & $\begin{array}{l}\text { Adult feeding behavior, neuro-peptide signaling } \\
\text { pathway and hormone-mediated signaling }\end{array}$ \\
\hline nSREBP-1 & & 107606 & 184756 & 3079 & rc_AI013042_at & $\begin{array}{l}\text { transcription } \\
\text { regulator activity }\end{array}$ & $\begin{array}{l}\text { Regulation of lipid metabolic process, steroid } \\
\text { metabolic process, cholesterol metabolic process } \\
\text { and regulation of transcription }\end{array}$ \\
\hline FOXO1 & Adipose tissues & 1890077 & 136533 & 1527 & rc_AA893671_at & $\begin{array}{l}\text { transcription factor } \\
\text { activity }\end{array}$ & $\begin{array}{l}\text { - Regulation of transcription } \\
\text { - regulation of cell proliferation }\end{array}$ \\
\hline 11b-HSD-1 & $\begin{array}{l}\text { Visceral adipose } \\
\text { tissue }\end{array}$ & 103562 & 600713 & 68471 & & $\begin{array}{l}\text { dehydrogenase activity and } \\
\text { oxidoreductase activity }\end{array}$ & Lipid metabolic process \\
\hline Apelin & Adipocytes & 1353624 & 300297 & 8498 & A_43_P12613 & Hormone activity & $\begin{array}{l}\text { - Plays a role in regulation of blood pressure } \\
\text { - Stimulate gastric cell proliferation }\end{array}$ \\
\hline Vaspin & $\begin{array}{l}\text { Visceral adipose } \\
\text { Tissue }\end{array}$ & 891971 & 107400 & 20103 & A_44_P288224 & Hormone activity & $\begin{array}{l}\text { regulates glucose tolerance and } \\
\text { insulin sensitization }\end{array}$ \\
\hline
\end{tabular}

\subsection{Second Phase (Databases Analysis)}

The second phase of the research analyzes the gene orthologs and the gene ontology (Table 2 and 3 respectively) of the 21 detected genes. The data pertaining to these genes/proteins obtained from the databases that are available online for free access.

\section{DISCUSSION}

The emerging epidemic of diabetes in Egypt and around the world cannot be ignored. According to the
World Health Organization, over 180 billion people now have diabetes worldwide and this number is expected to double by the year 2030 (WHO, 2008). Similarly alarming is the high prevalence of two factors closely linked with increased risk for diabetes: Metabolic Syndrome (MetS) and obesity (Pradhan, 2007). Several recent studies investigated that, a number of common factors including genetic predisposition, poor dietary patterns, increased physical inactivity and longer life expectancy contribute to the rising prevalence of these disorders; subclinical inflammation may represent an additional novel risk factor. In this regard, epidemiologic data suggest that inflammatory biomarkers 
may serve as important risk indicators for the future development of diabetes (Moller et al., 2003; Ford et al., 2004; Chew et al., 2006; Ogden et al., 2006; Shoelson et al., 2006; Ocana et al., 2010).

Also, there is growing evidence that the insulinresistance syndrome associated to obesity is mainly caused by excessive accumulation of fat in intraabdominal adipocytes (Macor et al., 1997; Kahn and Flier, 2000). It has been observed that the surgical removal of visceral fat improves insulin effect on hepatic glucose production in animal models of obesity (Barzilai et al., 1999). Adipose cells from visceral or subcutaneous depots largely differ concerning their metabolic characteristics as the control of lipolysis and the sensitivity to insulin (Wajchenberg, 2000). Therefore, it would be interesting to define the regional adipose differences in the expression of the recently discovered proteins, which are candidate links between fat accumulation and insulin resistance.

Complex traits such as obesity and type- 2 diabetes pose special challenges for genetic analyses because of gene-gene and gene-environment interactions, genetic heterogeneity and low penetrance of the individual genes. The heterogeneity means that it is difficult to generalize genome scan results over different populations and ethnicities. In addition, the exponential and alarming growth of the obesity epidemic has led scientists to begin to take advantage of proteomics to identify obesity molecular targets and to study the mechanisms of action of potential obesity therapies. Proteomics analyses have been proven useful in the characterization of the adipocyte proteome (Adachi et al., 2007), in the identification of obesity targets in different models of experimental obesity and to characterize targets of several agents such as the insulin sensitizer rosiglitazone (Sanchez et al., 2003). Although they are highly informative, these strategies often generate large amounts of data and long lists of proteins that are difficult to analyze and understand their biological importance.

The approach in this article is similar to the one in Rao et al. (2008) and Park et al. (2009), but it is more robust to the data here, which are more heterogeneous and encompassing the bioinformatic gene analysis of human, mouse and rat models in addition to other variables.

The present bioinformatic analysis showed significant relationships between metabolic and obesity type-2 diabetes disease risk factors and abdominal subcutaneous adipose tissue gene expression.

Recently, You et al. (2005) investigated that, the quantity of visceral fat was negatively related to leptin and adiponectin abdominal adipose tissue gene expression. In addition, hyperinsulinemia, as indicated by fasting insulin and 2-h insulin during the Oral Glucose Tolerance Test (OGTT), was positively associated with adipose TNF-a and IL-6 gene expression. Also, Elbers et al. (2007) yielded an interesting list of candidate genes by investigating the overlapping chromosomal linkage regions for type- 2 diabetes and obesity, using a combination of six computational disease gene identification methods. Many of these identified genes are excellent candidates to study further for their role in the shared disease aetiology between obesity and type-2 diabetes and a few have already been genetically or functionally associated with both disorders.

Current evidence supports that metabolic risk factors, including dyslipidemia, glucose intolerance and hyperinsulinemia, are linked with circulating levels of inflammatory and thrombotic cytokines (Chan et al., 2002; Bonora et al., 2003; Lyon and Hsueh, 2003). Relationships between cytokine gene expression in adipose tissue and metabolic risk and insulin resistance have been reported as well (Garaulet et al., 2004; Koistinen et al., 2000). Abdominal adipose gene expression levels of TNF-a (Koistinen et al., 2000), IL-6 (Rotter et al., 2003) and PAI-1 (Koistinen et al., 2000) are positively linked with insulin resistance and other cardiovascular risk factors, whereas adiponectin gene expression is negatively associated with metabolic variables (Garaulet et al., 2004). Our results were consistent with these previous findings and demonstrated that hyperinsulinemia was positively linked to adipose TNF-a and IL-6 gene expression and hyperinsulinemia and glucose intolerance were negatively linked to adipose adiponectin expression. Although these adipose-derived cytokines are traditionally viewed as the causes of the insulin resistance and metabolic risk (Rotter et al., 2003), recent evidence suggests that an elevated TNF-a and IL-6 expression (Krogh-Madsen et al., 2004) and a decreased adiponectin expression (Fasshauer et al., 2004) may also be a consequence of hyperinsulinemia. However, insulin infusion did not affect adiponectin gene expression in either healthy or type 2 diabetic individuals (Koistinen et al., 2004). Therefore, this study provides information from previous literatures and genome databases of different websites and act as a material for future studies to clarify the underlying mechanisms of these associations and finding of new therapies of obesity associated type 2 diabetes mellitus.

\section{CONCLUSION}

In conclusion, any rigid assessment of disease patterns will need support from well documented and curated databases. However, there are also several practical and 
theoretical constraints known if applying bioinformatics as a tool for improved understanding and diagnostics of disease patterns. So that, the current study provides evidence that the quantity of visceral fat and glucose/insulin complications of obesity is related to abdominal subcutaneous adipose tissue cytokine gene expression. Moreover, additional research is needed to discern whether abdominal subcutaneous adipocyte gene expression is causative for these risk factors or whether there is compensatory regulation of adipose tissue gene expression as a result of elevated visceral fat and/or insulin resistance.

\section{ACKNOWLEDGMENT}

The article is a part of a project that was funded by STDF. Thus, the authors acknowledge the Science and Technology Development Fund (STDF) Agency, Minister of Scientific Research, Egypt, for funding and following up the project.

\section{REFRENCES}

Adachi, J., C. Kumar, Y. Zhang and M. Mann, 2007. Indepth analysis of the adipocyte proteome by mass spectrometry and bioinformatics. Mol. Cell Proteomics, 6: 1257-1273. PMID: 17409382

Antunna-Puente, B., B. Fevi, S. Fellahi and J.P. Bastard, 2008. Adipokines: The missing link between insulin resistance and obesity. Diabetes Metab., 34: 2-11. PMID: 18093861

Armoni, M., C. Harel, S. Karni, H. Chen and F. BarYoseph et al., 2006. FOXO1 represses peroxisome proliferative-activated receptor-1 and -2 gene promoters in primary adipocytes. J. Biol. Chem., 281: 19881-19891.

Backberg, M., N. Madjid, S.O. Ogren and B. Meister, 2004. Down-regulated expression of Agouti-Related Protein (AGRP) mRNA in the hypothalamic arcuate nucleus of hyperphagic and obese tub/tub mice. Brain Res. Mol. Brain Res., 125: 129-139. PMID: 15193430

Barzilai, N., L. She, B.Q. Liu, P. Vuguin and P. Cohen et al., 1999. Surgical removal of visceral fat reverses hepatic insulin resistance. Diabetes, 48: 94-98. PMID: 9892227

Bastard, J.P., M. Maachi, C. Lagathu, M.J. Kim and M. Caron et al., 2006. Recent advances in the relationship between obesity, inflammation and insulin resistance. Eur. Cytokine Netw., 17: 4-12. PMID: 16613757

Binder, B.R., G. Christ, F. Gruber, N. Grubic and P. Hufnag et al., 2002. Plasminogen activator inhibitor 1: Physiological and pathophysiological roles. News Physiol. Sci., 17: 56-61. PMID: 11909993
Bonadonna, R.C., L. Groop, N. Kraemer, E. Ferrannini and S. Del Prato et al., 1990. Obesity and insulin resistance in humans: A dose-response study. Metabolism, 39: 452-459. DOI: 10.1016/00260495(90)90002-T

Bonora, E., S. Kiechl, J. Willeit, F. Oberhollenzer and G. Egger et al., 2003. Metabolic syndrome: epidemiology and more extensive phenotypic description. Cross-sectional data from the bruneck study. Int. J. Obes. Relat. Metab. Disord., 27: 12831289. PMID: 14513078

Boullu-Ciocca, S., A. Dutour, V. Guillaume, V. Achard and C. Oliver et al., 2005. Postnatal diet-induced obesity in rats upregulates systemic and adipose tissue glucocorticoid metabolism during development and in adulthood: Its relationship with the metabolic syndrome. Diabetes, 54: 197-203. PMID: 15616029

Bray, G.A., 2004. Medical consequences of obesity. J. Clin. Endocr. Metab., 89: 2583-2589. PMID: 15181027

Brown, M.S. and J.L. Goldstein, 1997. The SREBP pathway: Regulation of cholesterol metabolism by proteolysis of a membrane-bound transcription factor. Cell, 89: 331-340. PMID: 9150132

Carey, R., I. Jurickova, E. Ballard, E. Bonkowski and X. Han et al., 2008. Activation of an IL-6:STAT3dependent transcriptome in pediatric-onset inflammatory bowel disease. Inflamm. Bowel. Dis., 14: 446-457. PMID: 18069684

Cash, J.L., R. Hart, A. Russ, J.P. Dixon and W.H. Colledge et al., 2008. Synthetic chemerin-derived peptides suppress inflammation through ChemR23. J. Exp. Med., 205: 767-775 .DOI: 10.1084/jem.20071601

Chan, J.C., J.C. Cheung, C.D. Stehouwer, J.J. Emeis and P.C. Tong et al., 2002. The central roles of obesityassociated dyslipidaemia, endothelial activation and cytokines in the metabolic syndrome--an analysis by structural equation modelling. Int. J. Obes. Relat. Metab. Disord., 26: 994-1008. PMID: 12080455

Chew, G.T., S.K. Gan and G.F. Watts, 2006. Revisiting the metabolic syndrome. Med. J., 185: 445-449. PMID: 17137436

Chung, H., E. Kim, D.H. Lee, S. Seo and S. Ju et al., 2007. Ghrelin inhibits apoptosis in hypothalamic neuronal cells during oxygen-glucose deprivation. Endocrinology, 148: 148-159. DOI: 10.1210/en.2006-0991 
Creemers, J.W., L.E. Pritchard, A. Gyte, P.L. Rouzic and S. Meulemans et al., 2006. Agouti-related protein is posttranslationally cleaved by proprotein convertase 1 to Generate Agouti-Related Protein (AGRP)83132: Interaction between AGRP83-132 and melanocortin receptors cannot be influenced by syndecan-3. Endocrinology, 147: 1621-1631. PMID: 16384863

De Souza, C.M., R.Z. Yang, M.J. Lee, N.M. Glynn and D.Z. Yu et al., 2007. Omentin plasma levels and gene expression are decreased in obesity. Diabetes, 56: 1655-1661. DOI: 10.2337/db06-1506

DeFronzo, R.A., R.C. Bonadonna and E. Ferrannini, 1992. Pathogenesis of NIDDM. A balanced overview. Diabetes Care, 15: 318-368. PMID: 1532777

Desbriere, R., V. Vuaroqueaux, V. Achard, S. BoulluCiocca and M. Labuhn et al., 2006. 11ßhydroxysteroid dehydrogenase type 1 mRNA is increased in both visceral and subcutaneous adipose tissue of obese patient. Obesity, 14: 794-798. DOI: 10.1038/oby. 2006.92

Desruisseaux, M.S., S. Nagajyothi, M.E. Trujillo, H.B. Tanowitz and P.E. Scherer, 2007. Adipocyte, adipose tissue and infectious disease. Infect. Immun., 75: 1066-1078. DOI: 10.1128/IAI.01455-06

Elbers, C.C., N.C. Onland-Moret, L. Franke, A.G. Niehoff and Y.T. van der Schouw et al., 2007. A strategy to search for common obesity and type 2 diabetes genes. Trends Endocrinol. Metab., 18: 1926. DOI: $10.1016 /$ j.tem.2006.11.003

Enriori, P.J., A.E. Evans, P. Sinnayah, E.E. Jobst and L. Tonelli-Lemos et al., 2007. Diet-induced obesity causes severe but reversible leptin resistance in arcuate melanocortin neurons. Cell Metab., 5: 181194. PMID: 17339026

Fasshauer, M., R. Paschke and M. Stumvoll, 2004. Adiponectin, obesity and cardiovascular disease. Biochimie, 86: 779-784. DOI: 10.1016/j.biochi.2004.09.016

Fliegner, D., D. Westermann, A. Riad, C. Schubert and E. Becher, 2008. Up-regulation of PPAR $\gamma$ in myocardial infarction. Eur. J. Heart Fail, 10: 30-38. DOI: 10.1016/j.ejheart.2007.11.005

Ford, E.S., W.H. Giles and A.H. Mokdad, 2004. Increasing prevalence of the metabolic syndrome among U.S. adults. Diabetes Care, 27: 2444-2449. PMID: 15451914

Fruhbeck, G., R. Nutr and J. Salvador, 2004. Role of adipokines in metabolism and disease. Nutr. Res., 34: 803-826.
Garaulet, M., N. Viguerie, S. Porubsky, E. Klimcakova and K. Clement et al., 2004. Adiponectin gene expression and plasma values in obese women during very-low-calorie diet. Relationship with cardiovascular risk factors and insulin resistance. J. Clin. Endocrinol. Metab., 89: 756-760. PMID: 14764792

Gedela, S., A.A. Rao and N.R. Medicherla, 2007. Identification of biomarkers for type 2 diabetes and its complications. Bioinform. Approach Int. J. Biomed. Sci.

Gerken, T., C.A. Girard, Y.C.L. Tung, C.J. Webby and V. Saudek et al., 2007. The obesity-associated FTO gene encodes a 2-oxoglutarate-dependent nucleic acid demethylase. Science, 318: 1469-1472. DOI: $10.1126 /$ science. 1151710

Ghigo, E., F. Broglio, E. Arvat, M. Maccario and M. Papotti et al., 2005. Ghrelin: More than a natural GH secretagogue and/or an orexigenic factor. Clin. Endocrinol., 62: 1-17. PMID: 15638864

Glatz, J.F., J.J. Luiken, E.A.V. Nieuwenhoven and G.J.V.D. Vusse, 1997. Molecular mechanism of cellular uptake and intracellular translocation of fatty acids. Prostaglandins Leukot. Essent. Fatty Acids, 57: 3-9. PMID: 9250601

Gualillo, O., J.R. Gonzalez-Juanatey and F. Lago, 2007. The emerging role of adipokines as mediators of cardiovascular function: Physiologic and clinical perspectives. Trends Cardiovasc. Med., 17: 275-283. DOI: $10.1016 / \mathrm{j} . \mathrm{tcm} .2007 .09 .005$

Guilherme, A., J.V. Virbasius, V. Puri and M.P. Czech, 2008. Adipocyte dysfunctions linking obesity to insulin resistance and type 2 diabetes. Nat. Rev. Mol. Cell Biol., 9: 367-377. DOI: 10.1038/nrm2391

Hamblin, M., L. Chang, Y. Fan, J. Zhang and Y.E. Chen, 2009. PPARs and the cardiovascular system. Antioxid. Redox. Signal., 11: 1415-1452. DOI: 10.1089/ars.2008.2280

Hermanowski-Vosatka, A., J.M. Balkovec, K. Cheng, H.Y. Chen and M. Hernandez et al., 2005. 11 betaHSD1 inhibition ameliorates metabolic syndrome and prevents progression of atherosclerosis in mice. J. Exp. Med., 202: 517-527. PMID: 16103409

Hertig, A. and E. Rondeau, 2004. Plasminogen activator inhibitor type 1: The two faces of the same coin. Curr. Opin. Nephrol. Hypertens, 13: 39-44. PMID: 15090858

Hida, K., J. Wada, J. Eguchi, H. Zhang and M. Baba et al., 2005. Visceral adipose tissue-derived serine protease inhibitor: A unique insulin-sensitizing adipocytokine in obesity. Proc. Natl. Acad. Sci. USA., 102: 10610-10615. DOI: 10.1073/pnas.0504703102 
Higuchi, K., T. Masaki, K. Gotoh, S. Chiba and I. Katsuragi et al., 2007. Apelin, an APJ receptor ligand, regulates body adiposity and favors the messenger ribonucleic acid expression of uncoupling proteins in mice. Endocrinology, 148: 2690-2697. PMID: 17347313

Hotamisligil, G.S., 2006. Inflammation and metabolic disorders. Nature, 444: 860-867. PMID: 17167474

Kadowaki, T. and T. Yamauchi, 2005. Adiponectin and adiponectin receptors. Endocr. Rev., 26: 439-451. DOI: $10.1210 /$ er.2005-0005

Kahn, B.B. and J.S. Flier, 2000. Obesity and insulin resistance. J. Clin. Invest., 106: 473-481. PMID: 10953022

Kershaw, E.E. and J.S. Flier, 2004. Adipose tissue as an endocrine organ. J. Clin. Endocr. Metab., 89: 25482556. DOI: $10.1210 /$ jc.2004-0395

Khateeb, J., A. Gantman, A.J. Kreitenberg, M. Aviram and B. Fuhrman, 2010. Paraoxonase 1 (PON1) expression in hepatocytes is upregulated by pomegranate polyphenols: A role for PPAR-gamma pathway. Atherosclerosis, 208: 119-125. PMID: 19783251

Kim, K.H., K. Lee, Y.S. Moon and H.K. Sul, 2001. A cysteine-rich adipose tissue-specific secretory factor inhibits adipocyte differentiation. J. Biol. Chem., 276: 11252-11256. PMID: 11278254

Koistinen H.A., M. Forsgren, H. Wallberg-Henriksson and J.R. Zierath, 2004. Insulin action on expression of novel adipose genes in healthy and type 2 diabetic subjects. Obes. Res., 12: 25-31. PMID: 14742839

Koistinen, H.A., J.P. Bastard, E. Dusserre, P. Ebeling and N. Zegari et al., 2000. Subcutaneous adipose tissue expression of tumour necrosis factor-alpha is not associated with whole body insulin resistance in obese nondiabetic or in type-2 diabetic subjects. Eur. J. Clin. Invest., 30: 302-310. PMID: 10759878

Kojima, M. and K. Kangawa, 2005. Ghrelin: Structure and function. Physiol. Rev., 85: 495-522. DOI: 10. 1152/physrev.00012.2004

Kojima, M., H. Hosoda, Y. Date, M. Nakazato and H. Matsuo et al., 1999. Ghrelin is a growth-hormonereleasing acylated peptide from stomach. Nature, 402: 656-660. DOI: 10.1038/45230

Krogh-Madsen, R., P. Plomgaard, P. Keller, C. Keller and B.K. Pedersen, 2004. Insulin stimulates interleukin-6 and tumor necrosis factor-alpha gene expression in human subcutaneous adipose tissue. Am. J. Physiol. Endocrinol. Metab., 286: E234E238. PMID: 14532168
Li, Y., Y. Qi, T.H. Huang, J. Yamahara and B.D. Roufogalis, 2008. Pomegranate flower: A unique traditional antidiabetic medicine with dual PPARalpha/-gamma activator properties. Diabetes Obes. Metab., 10: 10-17. PMID: 18095947

Long, S., Y. Tian, R. Zhang, L. Yang and Y. Xu et al., 2006. Relationship between plasma HDL subclasses distribution and lipoprotein lipase gene HindIII polymorphism in hyperlipidemia. Clin. Chim. Acta, 366: 316-321. PMID: 16364275

Lupinacci, E., J. Meijerink, J. Vincken, B. Gabriele and H. Gruppen et al., 2009. anthohumol from hop (Humulus lupulus L.) is an efficient inhibitor of monocyte chemoattractant protein-1 and tumor necrosis factor-alpha release in LPS-stimulated RAW 264.7 mouse macrophages and U937 human monocytes. J. Agric. Food Chem., 57: 7274-7281. PMID: 19634869

Lyon, C.J. and W.A. Hsueh, 2003. Effect of plasminogen activator inhibitor-1 in diabetes mellitus and cardiovascular disease. Am. J. Med., 115: 62-68. DOI: 10.1016/j.amjmed.2003.08.014

Macor, C., A. Ruggeri, P. Mazzonetto, G. Federspil and C. Cobelli et al., 1997. Visceral adipose tissue impairs insulin secretion and insulin sensitivity but not energy expenditure in obesity. Metabolism, 46: 123-129. DOI: 10.1016/S0026-0495(97)90288-2

Masuzaki, H., J. Paterson, H. Shinyama, N.M. Morton and J.J. Mllins et al., 2001. A transgenic model of visceral obesity and the metabolic syndrome. Science, 294: 2166-2170. PMID: 11739957

Michalik, L., J. Auwerx, J.P. Berger, V.K. Chatterjee and C.K. Glass et al., 2006. International Union of Pharmacology. LXI. Peroxisome proliferatoractivated receptors. Pharmacol. Rev., 58: 726-741. PMID: 17132851

Moller, N., L. Gormsen, J. Fuglsang and J. Gjedsted, 2003. Effects of ageing on insulin secretion and action. Horm. Res., 60: 102-104. DOI: 10.1159/000071233

Nakae, J., T. Kitamura, Y. Kitamura, W.H. Biggs and K.C. Arden et al., 2003. The forkhead transcription factor FOXO1 regulates adipocyte differentiation. Dev. Cell, 4: 119-129. DOI: 10.1016/S15345807(02)00401-X

Nakae, J., W.H. Biggs, Y. Kitamura, W.H. Biggs and K.C. Arden et al., 2002. Regulation of insulin action and pancreatic beta-cell function by mutated alleles of the gene encoding forkhead transcription factor FOXO1. Nat. Genet., 32: 245-253. PMID: 12219087

Nakazato, M., N. Murakami, Y. Date, M. Kojima and H. Matsuo et al., 2001. A role for ghrelin in the central regulation of feeding. Nature, 409: 194-198. DOI: $10.1038 / 35051587$ 
Ocana, A., C. Gomez-Asensio, E. Arranz-Gutierrez, C. Torres and F.J. Senorans et al., 2010. In vitro study of the effect of diesterified alkoxyglycerols with conjugated linoleic acid on adipocyte inflammatory mediators. Lipids Health Disease, 9: 36-36. PMID: 20370890

Ogden, C.L., M.D. Carroll, L.R. Curtin, M.A. McDowell and C.J. Tabak et al., 2006. Prevalence of overweight and obesity in the united states, 19992004. JAMA, 295: 1549-1555. DOI: 10.1001/jama.295.13.1549

Ouchi, N., S. Kihara, T. Funahashi, Y. Matsuzawa and K. Walsh, 2003. Obesity, adiponectin and vascular inflammatory disease. Curr. Opin. Lipidol., 14: 561566. PMID: 14624132

Park, P.J., S.W. Kong, T. Tebaldi, W.R. Lai and S. Kasif et al., 2009. Integration of heterogeneous expression data sets extends the role of the retinol pathway in diabetes and insulin resistance. Bioinformatics, 25: 3121-3127. DOI: 10.1093/bioinformatics

Pradhan, A., 2007. Obesity, metabolic syndrome and type 2 diabetes: Inflammatory basis of glucose metabolic disorders. Int. Life Sci. Instit., 65: S152-S156. PMID: 18240540

Rabe, K., M. Lehrke, K.G. Parhofer and U.C. Broedl, 2008. Adipokines and insulin resistance. Mol. Med., 14: 741-751. DOI: 10.2119/2008-00058.Rabe

Rajala, M.W. and P.E. Scherer, 2003. Minireview: The adipocyte-at the crossroads of energy homeostasis, inflammation and atherosclerosis. Endocrinology, 144: 3765-3773. DOI: 10.1210/en.2003-0580

Rao, A.A., M. Tayaru, H. Thota, S.B. Changalasetty and L.S. Thota et al., 2008. Bioinformatic analysis of functional proteins involved in obesity associated with diabetes. Int. J. Biomed. Sci., 4: 70-73.

Rinninger, F., T. Kaiser, W.A. Mann, N. Meyer and H. Greten et al., 1998. Lipoprotein lipase mediates an increase in the selective uptake of high density lipoprotein-associated cholesteryl esters by hepatic cells in culture. J. Lipid Res., 39: 1335-1348. PMID: 9684736

Roh, S.G., S.H. Song, K.C. Choi, K. Katoh and V. Wittamer et al., 2007. Chemerin--a new adipokine that modulates adipogenesis via its own receptor. Biochem. Biophys. Res. Commun., 362: 1013-1018. PMID: 17767914

Rotter, V., I. Nagaev and U. Smith, 2003. Interleukin-6 (IL-6) induces insulin resistance in 3T3-L1 adipocytes and is, like IL-8 and tumor necrosis factor-alpha, overexpressed in human fat cells from insulin-resistant subjects. J. Biol. Chem., 278: 45777-45784. PMID: 12952969
Sanchez, J.C., V. Converset, A. Nolan, G. Schmid and S. Wang et al., 2003. Effect of rosiglitazone on the differential expression of obesity and insulin resistance associated proteins in lep/lep mice. Proteomics, 3: 1500-1520. PMID: 12923776

Scarlett, J.M., X. Zhu, P.J. Enriori, D.D. Bowe and A.K. Batra et al., 2008. Regulation of agouti-related protein messenger ribonucleic acid transcription and peptide secretion by acute and chronic inflammation. Endocrinology, 149: 4837-4845. PMID: 18583425

Shimomura, I., R.E. Hammer, J.A. Richardson, S. Ikemoto and Y. Bashmakov et al., 1998. Insulin resistance and diabetes mellitus in transgenic mice expressing nuclear SREBP-1c in adipose tissue: Model for congenital generalized lipodystrophy. Genes Dev., 12: 3182-3194. DOI: $10.1101 / \mathrm{gad} .12 .20 .3182$

Shoelson, S.E., J. Lee and A.B. Goldfine, 2006. Inflammation and insulin resistance. J. Clin. Invest., 116: 1793-1801. DOI: 10.1172/JCI29069

Simons, P.J., P.S.V.D. Pangaart, C.P.V. Roomen, J.M. Aerts and L. Boon, 2005. Cytokine-mediated modulation of leptin and adiponectin secretion during in vitro adipogenesis: Evidence that tumor necrosis factor-alpha- and interleukin-1beta-treated human preadipocytes are potent leptin producers. Cytokine, 32: 94-103. PMID: 16213747

Storch, J. and A.E. Thumser, 2000. The fatty acid transport function of fatty acid-binding proteins. Biochim. Biophys. Acta, 1486: 28-44. PMID: 10856711

Strauss, J.G., S. Frank, D. Kratky, G. Hammerle and A. Hrzenjak et al., 2001. Adenovirus-mediated rescue of lipoprotein lipase-deficient mice. Lipolysis of triglyceride-rich lipoproteins is essential for high density lipoprotein maturation in mice. J. Biol. Chem., 276: 36083-36090. PMID: 11432868

Takahashi, M., Y. Takahashi, K. Takahashi, F.N. Zolotaryov and K.S. Hong et al., 2008. Chemerin enhances insulin signaling and potentiates insulinstimulated glucose uptake in 3T3-L1 adipocytes. FEBS Lett., 582: 573-578. PMID: 18242188

Tran, H., A. Brunet, E.C. Griffith and M.E. Greenberg, 2003. The many forks in FOXO's road. Sci. STKE, 172: RE5- RE5. PMID: 12621150

Trayhum, P. and J.H. Beattie, 2001. Physiological roles of adipose tissue: White adipose tissue as an endocrine and secretory organ. Proc. Nut. Soc., 60: 329-339. PMID: 11681807 
Wajchenberg, B.L., 2000. Subcutaneous and visceral adipose tissue: Their relation to the metabolic syndrome. Endocr. Rev., 21: 697-738. DOI: 10.1210/er.21.6.697

Wallberg, A.E., S. Yamamura, S. Malik, B.M. Spiegelman and R.G. Roeder, 2003. Coordination of p300-mediated chromatin remodeling and TRAP/mediator function through coactivator PGC1alpha. Mol. Cell, 12: 1137-1149. PMID: 14636573

Wang, H. and R.H. Eckel, 2009. Lipoprotein lipase: From gene to obesity. Am. J. Physiol. Endocrinol. Metab., 297: E271-E288. DOI: 10.1152/ajpendo. 90920.200

Wang, K., Y. Chuan-Ping, W. Wei, Y. Zhan-Qing and C. Wei et al., 2010. Expression of interleukin 6 in brain and colon of rats with TNBS-induced colitis. World J. Gastroenterol., 16: 2252-2259. PMID: 0458762

WHO, 2008. Obesity and overweight. World Health Organization, Geneva.

Xiao, E., L. Xia-Zhang, N.R. Vulliemoz, M. Ferin and S.L. Wardlaw, 2003. Agouti-related protein stimulates the Hypothalamic-Pituitary-Adrenal (HPA) axis and enhances the HPA response to interleukin-1 in the primate. Endocrinology, 144: 1736-1741. PMID: 12697678
Yang, Q., T.E. Graham, N. Mody, O.D. Preitner and Peroni et al., 2005. Serum retinol binding protein 4 contributes to insulin resistance in obesity and type 2 diabetes. Nature, 436: 356-362. DOI: 10.1038/nature03711

Yang, R.Z., M.J. Lee, H. Hu, J. Pray, H.B. Wu, B.C. Hansen et al., 2006. Identification of omentin as a novel depot-specific adipokine in human adipose tissue: Possible role in modulating insulin action. Am. J. Phys. Endocrinol. Metab., 290: E1253-1261. PMID: 16531507

You, T., R. Yang, M.F. Lyles, D. Gong and B.J. Nicklas, 2005. Abdominal adipose tissue cytokine gene expression: relationship to obesity and metabolic risk factors. Am. J. Physiol. Endocrinol. Metab., 288: E741-E747. DOI: 10.1152/ajpendo.00419.2004 